\title{
The Reform Status and Model Construction of College Physical Education under the Sunshine Sports Background
}

Tao Huang

College of Physical Education, Taishan University 271000

Abstract: The implementation of quality education reform has made people gradually realize the positive significance of physical education on students' psychological qualities, physical literacy and sports concepts, and have sought effective teaching methods in hope of promoting students' enthusiasm in participating in sports. The physical education class is conducted in an orderly manner. Based on the background of sunshine sports, this article explores its positive significance for promoting the reform of physical education classrooms in colleges and universities, and finds specific ways to construct high-quality physical education classrooms in combination with specific teaching situations, hoping to provide reference for other teachers.

Keywords: Model construction; sunshine sports; sports classroom; higher education

With the gradual rise of cultural soft power with the development of the times, the majority of educators have gradually recognized the positive significance of the smooth development of physical education activities for the future development of students, and actively looking for effective teaching methods, hoping to enable students to participate in physical education classrooms It not only establishes a healthy and upward sports concept, but also can strengthen one's own willpower and hard-working spirit while building up a healthy body, laying the foundation for better development in the future. Sunshine sports as a new teaching perspective, while taking higher education as a model, through various sports activities that can attract students' enthusiasm for sports, so that they can feel the fun of participating in sports and continue to enhance the process of learning enthusiasm In order to achieve the purpose of exercising students' physical fitness. Therefore, how to ensure the high quality of sports classroom teaching activities under the background of sunshine sports is the key research issue of this article.

\section{The Reform Status of Physical Education Classroom in Colleges and Universities in Sunshine Sports}

Sports classrooms based on outdated teaching methods not only make students less active in participating in sports, but also the boring teaching mode is difficult to coordinate with the actual learning needs of students, which makes it difficult to achieve good results in classroom teaching. The concept of sunshine sports has made teachers break through the constraints of old teaching views, not only enriching the content of the teaching, but also reforming the teaching methods, which plays a positive role in training students' physical qualities and sports spirit. .

First, as a key course in the education system of our country, many college teachers often use gymnastics and ball sports as the main content when arranging teaching content, and seriously ignore the personalized development of students. The introduction of the concept of Sunshine Sports has allowed teachers to extend the content of the lectures. Through the inspection of the actual sports venues of the school and the characteristics of the students' overall interest, not only have they added more advanced sports facilities, but also added more in the curriculum. A project that can meet

Copyright (C) 2020 Tao Huang

doi: $10.18282 /$ le.v9i6.1284

This is an open-access article distributed under the terms of the Creative Commons Attribution Non-Commercial License

(http://creativecommons.org/licenses/by-nc/4.0/), which permits unrestricted non-commercial use, distribution, and reproduction in any medium, provided the original work is properly cited. 
the sports needs of different students. A variety of physical education classroom teaching not only greatly mobilizes the enthusiasm of students to participate in classroom learning, but also helps students to establish lifelong sports values while achieving better development.

Second, the introduction of the Sunshine Sports has made teachers realize that a single teaching method is the key to affecting students' enthusiasm for participation. Therefore, many sports teachers are more active in innovating teaching methods, hoping to enable students to complete the learning of sports classroom knowledge in a harmonious and relaxed sports environment. At the same time, teachers also pay more attention to respecting the student's subjective status, and no longer regard themselves as the classroom teaching center, but guide students to grasp the rhythm of movement in the exercise of subjective initiative, so that students can better meet their needs. In the sports program, the purpose of physical fitness is achieved.

\section{Specific ways for the smooth progress of physical education classes in colleges and universities in sunshine sports}

\subsection{Reasonable design of layered teaching mode}

Due to the wide range of students enrolled in colleges and universities, physical education teachers are often faced with uneven physical qualities, poor sports enthusiasm and obvious differences in sports foundations when conducting teaching activities. In order to ensure the smooth progress of classroom teaching activities, teachers can realize the importance of respecting students' actual sports needs and personalized development in the concept of sunshine sports. Through the construction of a layered teaching model, they can meet the requirements of students' sports and promote The purpose of rapid improvement of teaching effectiveness.

Therefore, teachers can divide the teaching content according to the actual teaching. For example, for freshman freshmen, the teacher can focus on teaching the basic knowledge; for the sophomore and junior students, the teacher needs to The actual situation of students design special sports teaching, so that students can complete their studies in sports that meet their sports needs and learning interests; and for senior students, they often face employment pressure, and teachers can focus on teaching In a sports program that prefers to relax, and to develop a training plan for students to improve their physical fitness, students can have a strong body and healthy spirit, while welcoming their future life and work in a better state.

\subsection{Implement the teaching model that combines theory and practice}

The concept of sunshine sports not only requires teachers to help students have a strong body and perseverance in teaching, but also needs to guide students to establish a lifelong sports concept while being able to greet the future with a more positive and sunny attitude. Therefore, education classroom teaching activities should not be confined to the classroom. Teachers also need to carry out extracurricular practical activities to enable students to truly generate enthusiasm for participating in sports in the teaching mode that integrates theoretical and practical teaching activities. Therefore, teachers can encourage students to use the time after class, actively participate in various sports competitions, and enrich themselves in rich practical activities, in order to get better development under the leadership of the spirit of sunshine sports.

\section{Conclusion}

Higher education aims at cultivating high-quality talents that can promote better development of society. Therefore, while learning professional knowledge and vocational skills, students also need to shoulder the historical mission of achieving national revitalization. This requires students to have a strong physique and persevering spiritual concepts, in order to grow into a pillar of talent for national development. Therefore, physical education teachers in colleges and universities need to improve physical education classroom teaching activities under the background of sunshine sports, and find teaching methods that can fully stimulate students' enthusiasm to participate in sports. The purpose of the future 
vigorous development of physical education.

\section{References}

1. Wang Yong, Zhang Yujie. Research on the application of flipped classroom based on micro-classes in college physical education major courses[J]. Chinese Journal of Multimedia and Network Teaching (Early Issue), 2020(06):32-33.

2. Duan Jing, Huang Jianjun, Zhang Hongtao. Effective classroom teaching of physical education in colleges and universities under the guidance of core literacy [C]. Professional Committee of Education and Teaching Innovation of China Education Development Strategy Society. Proceedings of the 2020 National Forum on Education and Teaching Innovation and Development (Volume 1) .Education and Teaching Innovation Professional Committee of China Education Development Strategy Society, 2020:407-408.

3. Ai Anli. A new exploration of the teaching mode of "bipartite classroom" of physical education theory in colleges and universities__ Taking "Sports and Health Subject Knowledge and Teaching Ability" as an example[J]. Sports Science and Technology Literature Bulletin, 2019, 27(12): 9-11. 